\title{
Mice lacking TNF $\alpha$ receptors 1 and 2 are resistant to death and fulminant liver injury induced by agonistic anti-Fas antibody
}

\author{
P Costelli*,1, P Aoki ${ }^{2}$, B Zingaro ${ }^{3}$, N Carbó ${ }^{4}$, P Reffo ${ }^{1}$, \\ FJ Lopez-Soriano ${ }^{4}$, G Bonelli ${ }^{1}$, JM Argilés ${ }^{4}$ and FM Baccino ${ }^{1}$ \\ 1 Dipartimento di Medicina e Oncologia Sperimentale, Università di Torino, Italy \\ 2 Department of Clinical Chemistry, Faculty of Chemical Science, National \\ University of Cordoba, Argentina \\ ${ }^{3}$ Dipartimento di Patologia Clinica, Ospedale 'SS Annunziata', Savigliano, \\ Italy \\ ${ }^{4}$ Departament de Bioquimica i Biologia Molecular, Universitat de Barcelona, \\ Spain \\ * Corresponding author: P Costelli, Dipartimento di Medicina e Oncologia \\ Sperimentale, Università di Torino, Corso Raffaello, 30, 10125 Torino, Italy. \\ Tel: + 39011 6707759; Fax: + 39011 6707753; \\ E-mail: paola.costelli@unito.it
}

Received 08.11.02; revised 15.4.03; accepted 24.4.03 Edited by G. Ciliberto

\begin{abstract}
The liver is particularly susceptible to Fas-mediated cytotoxicity. Mice given an adequate parenteral dose of agonistic antiFas antibody (aFas) or of FasL are known to develop a devastating liver injury and to die in a few hours. The present work shows that mice lacking TNFR1 and TNFR2 $\left(\mathbf{R}^{-}\right)$both survive a single dose of aFas, otherwise rapidly lethal, and develop a mild form of hepatic damage, compared to the much more severe liver injury that in a few hours strikes wildtype mice $\left(\mathbf{R}^{+}\right)$, eventually involving increased activity of proteases of different families (caspase 3-, 8-, and 9-like, calpains, cathepsin B). Neither the overall tissue levels of Fas and FasL nor Fas expression at the hepatocyte surface are altered in the liver of $\mathbf{R}^{-}$animals. The DNA-binding activity of the NF- $\kappa$ B transcription factor is enhanced after aFas treatment, but much more markedly in $\mathbf{R}^{-}$than in $\mathbf{R}^{+}$mice. $B c 12$, while unchanged in untreated animals, is markedly upregulated in $\mathbf{R}^{-}$but not in $\mathbf{R}^{+}$mice challenged with aFas. The requirement of a normal TNFR1/TNFR2 phenotype for full deployment of the general and liver-specific aFas toxicity in mice most likely implies that treatment with aFas in some way results in activation of the TNF $\alpha$-TNFRs system and that this activation synergizes with Fas-mediated signals in causing the fulminant liver injury and the animal death. The precise cellular and molecular details underlying this interplay between Fas- and TNFRs-mediated signaling systems in the general and liver-specific aFas toxicity largely remain to be clarified.

Cell Death and Differentiation (2003) 10,997-1004. doi:10.1038/ sj.cdd. 4401281
\end{abstract}

Keywords: apoptosis; Fas; TNF; TNF receptors; knockout mice

\begin{abstract}
Abbreviations: aFas, agonistic anti-Fas antibody; $\mathrm{R}^{+}$, normal
\end{abstract} mice; $R^{-}$, mice knocked out for TNF-R1 and TNF-R2

\section{Introduction}

Fas, also known as CD95, Apo1, or TNFRSF6, is a type I transmembrane protein belonging to the tumor necrosis factor receptor superfamily (TNFRSF). Although also reported to convey survival/proliferation signals, ${ }^{1-3}$ Fas is canonically viewed as a death receptor (reviewed by Budd ${ }^{3}$, Nagata and Gostein ${ }^{4}$ ). Fas engagement and oligomerization by its ligand (FasL, TNFSF6) or by agonistic antibodies result in recruitment of the adapter protein FADD and procaspase- 8 onto the death domain (DD) in its cytoplasmic tail. Proteolytic autoactivation of caspase-8 is followed by processing of effector procaspases into their active forms, leading to apotosis execution. In some cells, categorized as type I, this 'extrinsic' pathway is adequate to perform Fas-induced apoptosis, while type II cells require activation of the 'intrinsic' or mitochondrial pathway, mainly via a truncated form of Bid (tBid) generated by caspase- $8{ }^{5,6}$

In the liver, Fas-mediated apoptosis is thought to be involved in hepatocyte homeostasis and to play important roles in a variety of diseases (reviewed by Pinkoski et al. ${ }^{7}$ ). Fas expression on the hepatocyte surface is increased in acute liver failure ${ }^{8}$ or in chronic viral hepatitis B or C, positively correlating with the severity of the process. ${ }^{9,10}$ In addition, high circulating levels of FasL and soluble Fas have been detected in viral or autoimmune chronic hepatitis, cirrhosis, or toxic hepatitis. ${ }^{411-13}$ The liver indeed is particularly susceptible to Fas-mediated cytotoxicity, as illustrated by the devastating hepatic injury with massive hepatocyte apoptosis and eventual death of the animals triggered in a few hours by agonistic anti-Fas antibody (aFas) or FasL in mice. ${ }^{13,14}$ This model has been largely used as an experimental equivalent of fulminant human hepatitis.

TNF $\alpha$ (TNFSF2) is a pleiotropic cytokine that can promote such diverse effects as cell proliferation, differentiation, survival, or death, being involved in a variety of physiological and pathological processes. Two different receptors, p55 TNFR1 (TNFRSF1A) and p75 TNFR2 (TNFRSF1B), transduce the TNF $\alpha$ signal. TNFR1 is a death receptor whose DD upon ligand binding and receptor oligomerization recruits the adapter protein TRADD that provides docking sites for FADD and procaspase-8; the apoptotic cascade then progresses along the extrinsic or, frequently, the intrinsic pathway as reported above (reviewed by Ledgerwood et al. ${ }^{15}$ ). In addition, TNFR1 also transduces survival signals resulting in activation and nuclear translocation of the transcription factor NF- $\kappa \mathrm{B}$, or in activation of members of the MAPK cascade. ${ }^{2}$ In fact, TNF $\alpha$ may act as a double-edged sword by virtue of the multiplicity of signals it evokes, the final outcome of which will depend on 
their balance as well as on the nature and recent history of the target cells.

The liver provides a well-known example for the dichotomy between trophic/mitogenic and cytotoxic effects of TNF $\alpha$. A sound body of evidence substantiates the notion that TNF $\alpha$ can trigger hepatocyte proliferation in vitro ${ }^{16,17}$ as well as in vivo (reviewed by Michalopoulos and DeFrances ${ }^{18}$ ), and that normal hepatocytes are inherently resistant to TNF $\alpha$ toxicity. Thus, TNF $\alpha$ promotes regenerative liver growth, subsequent to partial hepatectomy ${ }^{19}$ or liver injury ${ }^{20}$, and growth elicited by agents such as gadolinium chloride ${ }^{21}$ or peroxisome proliferators. ${ }^{16}$ On the other side of the coin, TNF $\alpha$ has been involved in the induction of cell death in experimental hepatitis $^{22,23}$ and various liver diseases. ${ }^{24}$ Moreover, its action on normal liver or primary hepatocyte cultures can be shifted to cytotoxicity by suppressing NF- $\kappa$ B activation ${ }^{17,25-27}$ or by blocking macromolecular synthesis with translational/ transcriptional inhibitors such as cycloheximide, actinomycin $\mathrm{D}$, and galactosamine ${ }^{28}$ whose effect is attributed, in part at least, to inhibition of NF- $\kappa$ B-regulated gene expression. ${ }^{26,27}$

In view of (i) the above opposing actions of TNF $\alpha$ on hepatocytes, (ii) the notion that the cytotoxic TNFR1 and Fas signals converge onto the same FADD adapter and apoptotic cascades, and (iii) the hypothesis that endogenous TNF $\alpha$ might play a role in Fas-mediated liver injury, ${ }^{29,30}$ in the present study we compared the effects of a single dose of aFas in normal mice $\left(\mathrm{R}^{+}\right)$versus mice $\left(\mathrm{R}^{-}\right)$knocked out for both TNFR1 and TNFR2. ${ }^{20}$ The results neatly show that, while $\mathrm{R}^{+}$mice die within a few hours after challenge with aFas and develop a massive liver destruction, as originally shown by Ogasawara et al., ${ }^{14} \mathrm{R}^{-}$mice are still alive at $24 \mathrm{~h}$ and their liver substantially spared from injury. These findings strongly argue for TNF $\alpha$ as being critically involved in the fulminant liver damage and animal death triggered by Fas activation, although the precise cellular and molecular basis for the synergy between Fas and TNFRs signaling largely remain an open question.

\section{Results}

In a matter of hours, a single i.v. injection of aFas into mice is known to cause both a devastating liver injury, resembling fulminant hepatitis, and animal death, regarded as an aftermath of the liver damage. ${ }^{14}$ Consistently, in the present study $\mathrm{R}^{+}$mice died within 5-8h after an i.v. dose of $10 \mu \mathrm{g}$ aFas. By contrast, all $\mathrm{R}^{-}$animals were alive and looked healthy when killed, 10 or $24 \mathrm{~h}$ after treatment (Figure 1). At necropsy, the liver was swollen and highly congested in $\mathrm{R}^{+}$animals, but had a virtually normal appearance in the $\mathrm{R}^{-}$group.

Histologically, the aFas-induced liver injury drastically differed in severity between the two groups of animals. In $\mathrm{R}^{+}$mice, massive panlobular apoptosis and diffuse hemorrhage (peliosis hepatis) were prominent, while the hepatic microarchitecture was no longer discernible (Figure 2a). The tissue was crowded with apoptotic bodies, either still containing nuclear material or showing as acidophilic (Councilman) bodies, that were interspersed with scarce hepatocytes still recognizable (Figure 2a), usually exhibiting a grossly vacuolated cytoplasm. Electron microscopy confirmed the occur-

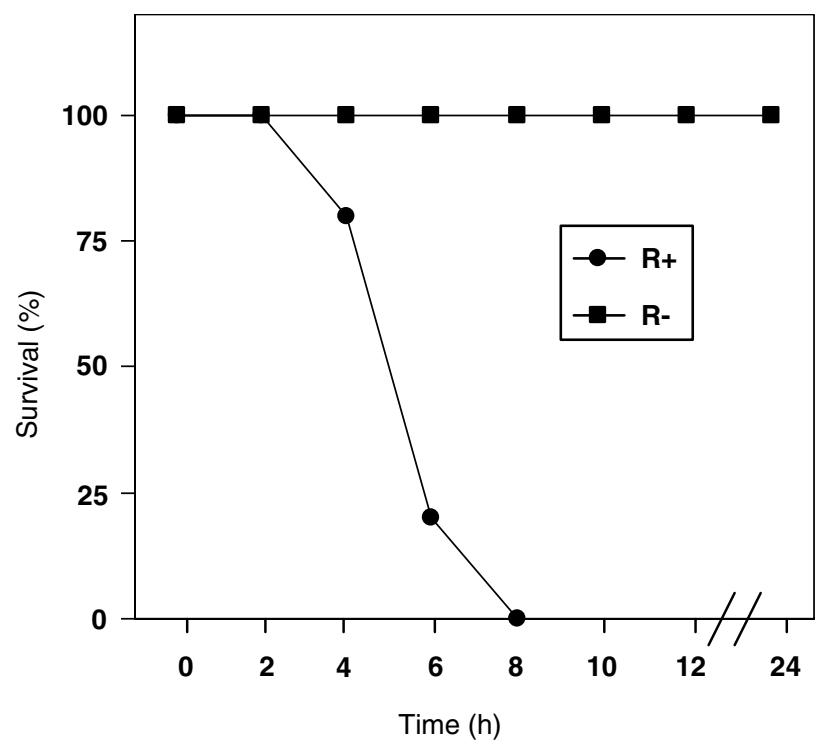

Figure 1 Resistance of $\mathrm{R}^{-}$mice to the lethal effect of aFas. Percent survival of wild-type ( $)$ and TNFRs-null ( $\mathbf{\square}$ ) animals in response to a single i.v. dose of aFas $(n=10)$
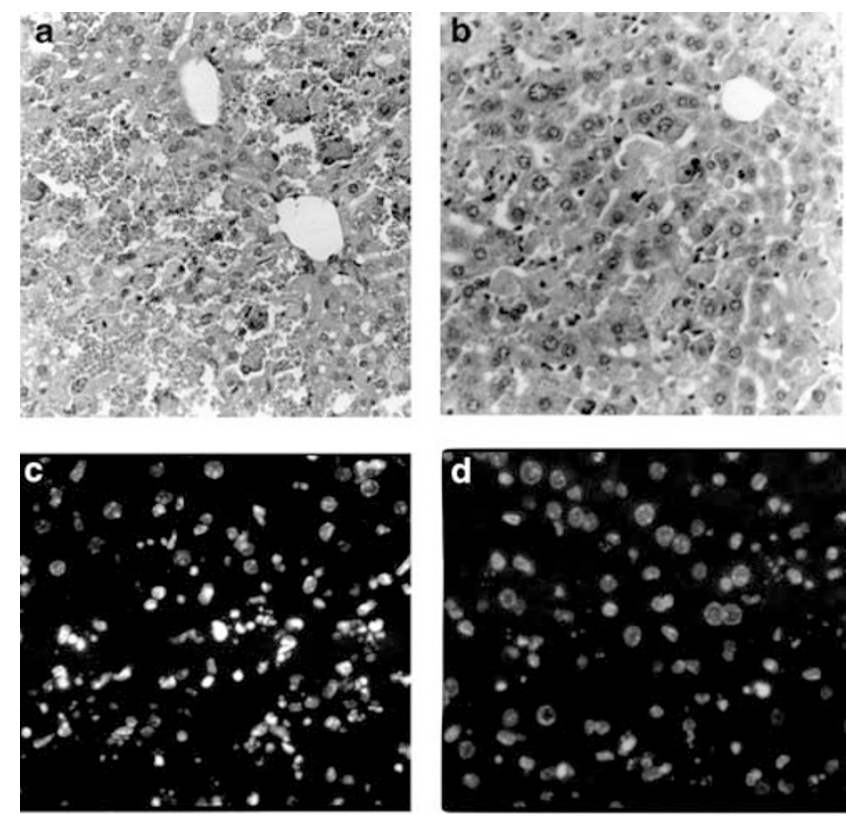

Figure 2 Histological appearance of the liver from $\mathrm{R}^{+}$and $\mathrm{R}^{-}$mice treated with aFas. Hematoxylin and eosin: $\mathrm{R}^{+}(\mathbf{a}), \mathrm{R}^{-}(\mathbf{b})$, magnification $\times 640$. DAPI: $\mathrm{R}^{+}(\mathbf{c}), \mathrm{R}^{-}(\mathbf{d})$, magnification $\times 640$

rence of extensive apoptosis, with a number of nuclei that showed the typical apoptotic morphology characterized by chromatin condensation, nucleolar segregation, and nuclear fragmentation (Figure 3a), while cytoplasmic organelles were relatively well preserved. Frequently, in the widespread areas of hemorrhage, dead cells appeared to float free among extravasated erythrocytes (Figure $3 \mathrm{~b}$ ). By contrast, in $\mathrm{R}^{-}$ mice, the lobular design and the characteristic radial distribution of hepatic trabeculae around the centrilobular vein were preserved, although in some animals discrete hemorrhagic 


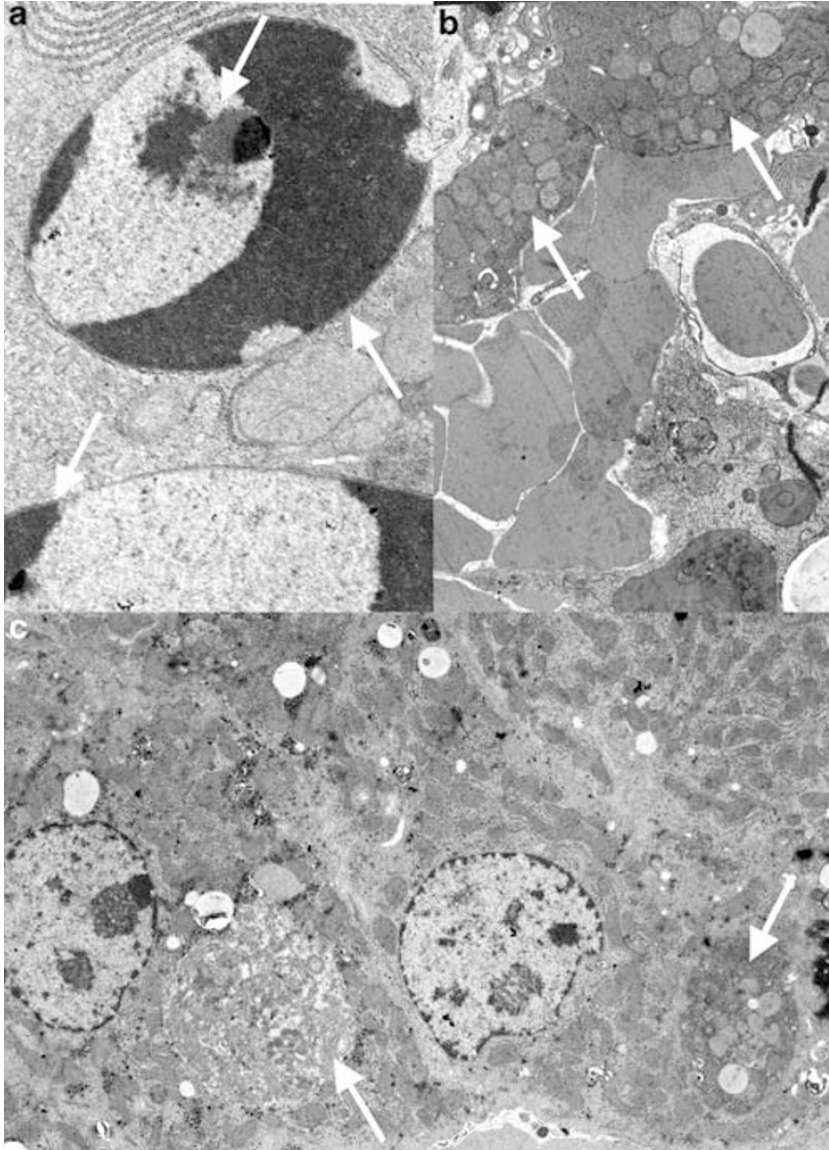

Figure 3 Transmission electron microscopy of the liver after aFas treatment. Panels $a$ and $b$ (magnification: $\times 12000), R^{+}$animals; panel a details the nuclear alteration: chromatin condensation and nucleolar segregation (arrows); panel $b$ shows some apoptotic bodies containing well recognizable cytoplasmic organelles (arrows). Panel c (magnification $\times 7100$ ) shows that the liver of $R^{-}$ mice is comparatively well preserved; the arrows indicate huge intracellular vacuoles, likely deriving from phagocytosis of apoptotic bodies

foci could be detected (Figure 2b). The number of apoptotic cells in $\mathrm{R}^{-}$livers, although quite remarkable compared to untreated animals, was drastically lower than in $\mathrm{R}^{+}$animals with dead cells distributed throughout the lobular zones, while most hepatocytes showed a marked cytoplasmic vacuolation (Figure 2b). Electron microscopy confirms that most hepatocytes show a fairly well-preserved morphology. Some of them contain huge vacuolar structures likely representing phagocytosed apoptotic bodies (Figure 3c). The marked difference between the two groups of mice in the frequency of apoptotic nuclei, showing condensed or marginated chromatin or frankly fragmented, is easily appreciated in preparations stained with the DAPI fluorochrome (Figures $2 \mathrm{c}$ and d).

Internucleosomal DNA fragmentation is an established, albeit not universal, hallmark of apoptotic cell death. Most DNA extracted from aFas-treated $\mathrm{R}^{+}$mice liver indeed appeared extensively degraded such as to produce a prominent 'ladder pattern' by agarose-gel electrophoresis, while DNA fragmentation, although still detectable, was much less pronounced in $\mathrm{R}^{-}$animals (Figure 4).
$\mathrm{R}^{+}$

$R^{-}$

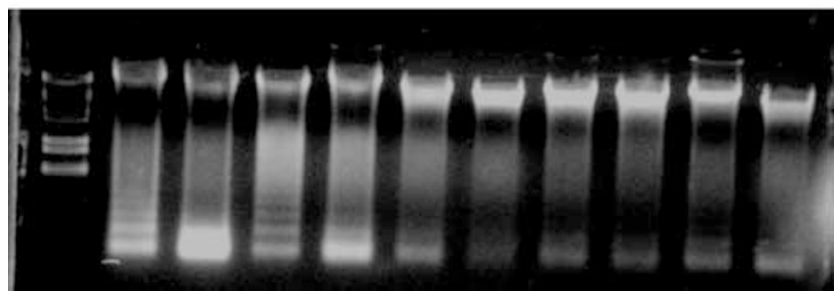

Figure 4 Agarose gel electrophoresis of DNA extracted from the liver of $\mathrm{R}^{+}$ and $R^{-}$animals treated with aFas $\left(5-8 h\right.$ for $R^{+}$and $10 h$ for $\left.R^{-}\right)$. Lane 1 : molecular weight markers, lanes $2-5: \mathrm{R}^{+}$mice; lanes $6-11: \mathrm{R}^{-}$mice

The induction of apoptosis typically requires activation of both initiator and effector caspases. Cotreatment with the pancaspase inhibitors Z-VAD-fmk ${ }^{31}$ or IDN-1965 $5^{32}$ indeed protects mice from aFas-induced liver injury. In the present experiments, caspase 3-, 8-, and 9-like activities were definitely lower in $\mathrm{R}^{-}$than in $\mathrm{R}^{+}$mice livers (Table 1 ), consistently with the different extent of apoptosis. Other proteolytic enzymes have been implicated in the apoptotic process: calpains have been shown to activate the caspase cascade in both $B$ and $T$ cells, to cleave the proapototic factor Bid, and to be involved in microcystin-induced apoptosis in isolated rat hepatocytes. ${ }^{33-36}$ Moreover, the lysosomal cathepsins $B$ and $D$ have been shown to play a role in $\mathrm{TNF} \alpha$-induced apoptosis of various cells, hepatocytes included. ${ }^{37-39}$ In the present study, both cathepsin B and, particularly, calpain activities were significantly higher in $\mathrm{R}^{+}$ than in $\mathrm{R}^{-}$animals treated with aFas (Table 1). Therefore, diverse proteolytic systems relevant to apoptosis were all more active in $\mathrm{R}^{+}$mice livers at a stage in which aFasinduced injury was fully developed, while in $\mathrm{R}^{-}$mice these proteolytic systems were much less active at the same time interval after aFas administration, further confirming that the lack of TNFRs confers resistance to aFas.

An obvious possible explanation for the different susceptibility of $\mathrm{R}^{-}$versus $\mathrm{R}^{+}$animals to Fas-induced liver injury is that abrogation of 'tonic' signaling from TNFRs may somehow downregulate Fas expression in the liver. ${ }^{40}$ By Western blotting, neither Fas nor FasL protein levels significantly differed between the two mice groups after aFas administration (Figure $5 \mathrm{a}, \mathrm{b}$ ). In addition, untreated $\mathrm{R}^{+}$and $\mathrm{R}^{-}$animals did not differ as to cell surface distribution of Fas (Figure 5C) and total Fas protein levels (data not shown).

Hepatocytes can be categorized as type II cells in that execution of Fas-mediated apoptosis requires activation of the 'intrinsic' or mitochondrial pathway (see Introduction). The latter is extensively modulated by pro- and antiapoptotic members of the Bcl-2 family. Consistently, expression of a $\mathrm{Bcl}-2$ transgene largely protects mice from aFas hepatic toxicity, ${ }^{41,42}$ although not necessarily from lethality, ${ }^{42}$ while increased hepatic $\mathrm{Bcl}-\mathrm{X}_{L}$ expression would account for the higher resistance to aFas of C/EBP knockout mice. ${ }^{43}$ In the present work, we examined the level of the antiapoptotic $\mathrm{Bcl}-2$ protein. Although not different in untreated animals, Bcl-2 
Table 1 Enzymatic activities in the liver of $\mathrm{R}^{+}$and $\mathrm{R}^{-}$mice after treatment with aFas

\begin{tabular}{lccrr}
\hline & \multicolumn{3}{c}{ Controls } & \multicolumn{2}{c}{ Treated with aFas } \\
\cline { 2 - 5 } & $\mathbf{R}^{+} \mathbf{( 5 )}$ & $\mathbf{R}^{-} \mathbf{( 5 )}$ & $\mathbf{R}^{+} \mathbf{( 8 )}$ & $\mathbf{R}^{-} \mathbf{( 8 )}$ \\
\hline Caspase 3 & $16.0 \pm 4.5$ & $21.0 \pm 9.4$ & $66.9 \pm 9.0^{*}$ & $23.3 \pm 3.2^{\star \star}$ \\
Caspase 8 & $27.2 \pm 9.0$ & $34.0 \pm 8.1$ & $88.1 \pm 13.6^{\star}$ & $31.3 \pm 9.4^{\star \star}$ \\
Caspase 9 & $21.4 \pm 11.1$ & $27.9 \pm 16.1$ & $139.2 \pm 34.0^{*}$ & $34.2 \pm 9.8^{* \star}$ \\
Calpain & $19.7 \pm 6.3$ & $19.0 \pm 7.0$ & $104.9 \pm 18.5^{*}$ & $29.5 \pm 7.9^{* \star}$ \\
Cathepsin B & $10.2 \pm 3.1$ & $10.9 \pm 1.1$ & $24.4 \pm 4.0^{*}$ & $10.6 \pm 4.4^{*}$ \\
\hline
\end{tabular}

Data (nkatal $\times 10^{-5} / \mathrm{mg}$ protein) expressed as means $\pm \mathrm{SD}$. No. of animals in brackets. The liver from $\mathrm{R}^{-}$mice has been collected between 5 and $8 \mathrm{~h}$ postinjection (immediately before the death of each animal), while $\mathrm{R}^{+}$mice were killed $10 \mathrm{~h}$ after anti-Fas administration (see Materials and Methods). Significance of the differences (ANOVA): ${ }^{*} P$ versus untreated $\mathrm{R}^{+} ;{ }^{* *} P$ versus treated $\mathrm{R}^{+}$.

a

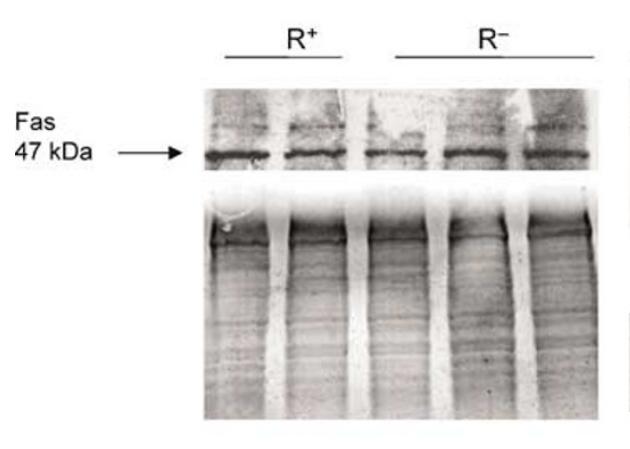

b

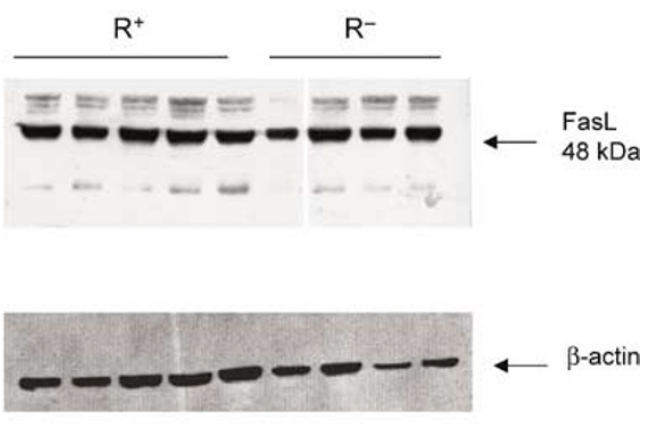

C

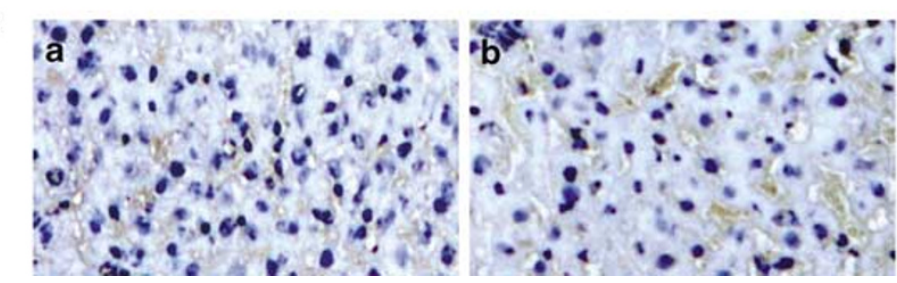

Figure 5 Fas and FasL expression in the liver of $\mathrm{R}^{+}$and $\mathrm{R}^{-}$mice. (a) Western blotting indicating Fas expression in aFas-treated mice; $\mathrm{R}^{+}$(lanes 1-2), $\mathrm{R}^{-}$(lanes $3-$ 5); (b) Western blotting analysis of FasL expression in aFas-treated animals, $R^{-}$(lanes 1-5), $R^{+}$(lanes 6-9); homogeneity of protein loading checked by Coomassie blue staining (Fas) or $\beta$-actin expression (FasL). Time after aFas treatment: $5-8 \mathrm{~h}$ for $\mathrm{R}^{+}$and $10 \mathrm{~h}$ for $\mathrm{R}^{-}$. (c) Immunohistochemical anaysis of Fas distribution in untreated $\mathrm{R}^{+}$(a) and $\mathrm{R}^{-}$(b) mice

markedly increased after aFas treatment in the liver of $\mathrm{R}^{-}$ mice only (Figure 6), raising the possibility that this response may contribute to their lower susceptibility to Fas engagement.

Finally, as a measure of its activation status, we evaluated the DNA-binding activity of the transcription factor NF- $\kappa \mathrm{B}$, which is known to modulate the cell response to death receptor signals and various other cellular stresses. Figure 7 shows that the DNA-binding activity of NF- $\kappa \mathrm{B}$, already detectable in ${ }^{1} R_{+}^{-}$though less than in ${ }^{2} R_{+}^{-}$controls, was enhanced moderately in $\mathrm{R}^{+}$mice and markedly in $\mathrm{R}^{-}$-mice after aFas treatment. Consistently with this result, the levels of the $1-\kappa B$ inhibitory subunit are reduced in both $R^{+}$- and $R^{-}$treated animals, although no clear differences can be observed between the two groups $\left(R^{+}: 13 \pm 3, R^{-}: 22 \pm 4\right.$ densitometric units). This lack of difference may depend from an increased $\mathrm{I}-\kappa \mathrm{B}$ production in the $\mathrm{R}^{-}$mice after aFas treatment, a well-known consequence of NF- $\kappa$ B activation. $\mathrm{R}^{-}$ animals are characterized by a higher basal activity of NF- $\kappa \mathrm{B}$, which does not associate with modulations in the levels of the inhibitory subunit $\mathrm{l}-\kappa \mathrm{B}(30 \pm 4$ and $38 \pm 6$ densitometric units in $\mathrm{R}^{+}$and $\mathrm{R}^{-}$mice, respectively). Moreover, in these animals, aFas treatment results in a much higher activation of this transcription factor. This differential may also concur to the higher resistance of $\mathrm{R}^{-}$mice to aFas.

\section{Discussion}

The present paper shows that mice lacking both TNFR1 and TNFR2 $\left(\mathrm{R}^{-}\right)$are resistant to a single dose of aFas, which is lethal for TNFR-expressing animals and that their liver is only mildly affected, compared to the devastating hepatic damage that in a few hours strikes wild-type mice. $\mathrm{R}^{-}$animals show no 
a

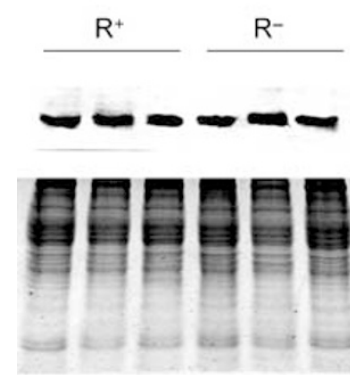

b

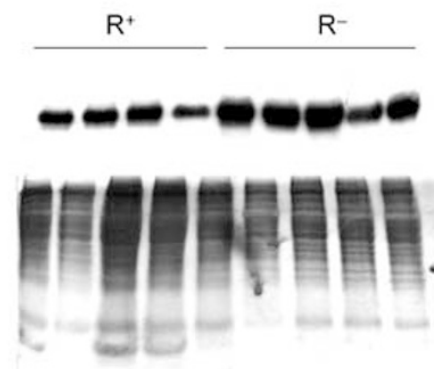

Figure 6 Western blots of $\mathrm{Bcl}-2$ in the liver of $\mathrm{R}^{+}$and $\mathrm{R}^{-}$mice before (a) and after (b) treatment with aFas (5-8 $h$ for $R^{+}$and $10 \mathrm{~h}$ for $\mathrm{R}^{-}$). (a) $\mathrm{R}^{+}$(lanes $1-3$ ), $R^{-}$(lanes 4-6), (b) $R^{+}$(lanes 1-4), $R^{-}$(lanes 5-9); homogeneity of protein loading checked by Coomassie Blue staining

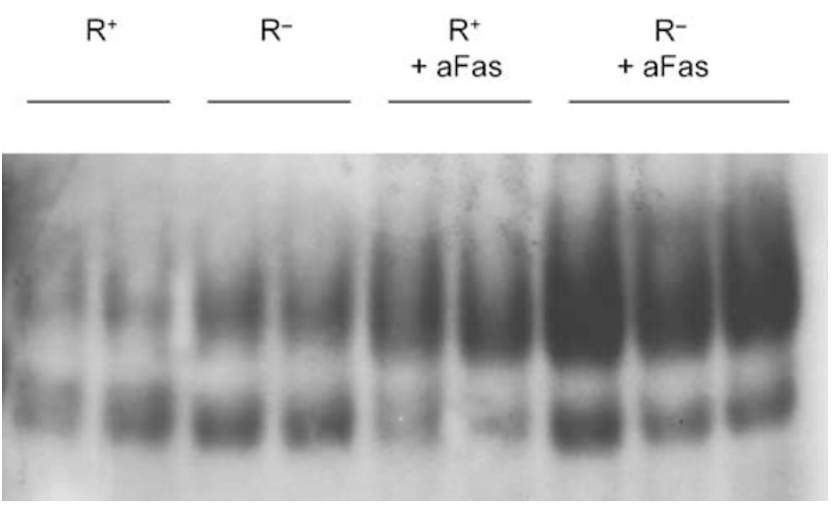

Figure 7 EMSA analysis of the DNA-ligand binding activity of NF-kB. Lanes 1-2 (untreated $\mathrm{R}^{+}$), 3-4 (untreated $\mathrm{R}^{-}$), 5-6 (aFas-treated $\mathrm{R}^{+}$5-8 h postinjection, 7-9 (aFas-treated $\mathrm{R}^{-}, 10 \mathrm{~h}$ postinjection)

alteration in the overall hepatic levels or the cell surface expression of Fas. A marked upregulation of $\mathrm{Bcl} 2$ expression occurs in $\mathrm{R}^{-}$though not in $\mathrm{R}^{+}$mice after challenge with aFas. In addition, the DNA-binding activity of the NF- $\kappa$ B transcription factor, already slightly higher in $\mathrm{R}^{-}$than in $\mathrm{R}^{+}$control animals, after aFas treatment is enhanced much more markedly in $\mathrm{R}^{-}$ than in $\mathrm{R}^{+}$mice. Therfore, the present evidence consistently demonstrates that a normal TNFR1/TNFR2 phenotype is required for full deployment of the aFas toxicity. These observations thus strongly suggest that treatment with aFas activates the TNF $\alpha$-TNFRs system, whose signaling, in synergy with that generated by Fas, appears to be required for fulminant liver injury and animal death to develop.

Protection against aFas toxicity has been afforded by various means, including pancaspase inhibitors ${ }^{31,32}$ or high tissue levels of $\mathrm{Bcl}-2$ or $\mathrm{Bcl}-\mathrm{X}_{\mathrm{L}}{ }^{41-43}$ Treatment with an IL15$\lg$ G2b fusion protein is also protective ${ }^{29}$ and activated IL $15 R \alpha$ has been shown to bind TRAF2, ${ }^{30}$ which is a major signal transducer for $\mathrm{TNF} \alpha$ as well as other cytokines and mostly plays a cytoprotective role, particularly via NF- $\kappa$ B activation (reviewed by Chung et al. $^{44}$ ). Evidence that may specifically support a synergic role for endogenous TNF $\alpha$ in aFas toxicity has been provided by a recent report ${ }^{45}$ showing that administration of aFas causes an increase of TNF $\alpha$ plasma levels and that partial protection from aFas-induced liver injury can be afforded by pretreating mice with gadolinium chloride, an agent that temporarily depletes the large periportal Kupffer cells. This observation led to depict Fas-mediated toxicity as a two-step process in which Fas causes Kupffer cells to release TNF $\alpha$ that in turn promotes hepatocyte death. ${ }^{45}$ In principle, this view is compatible with the present findings. However, in addition to Kupffer cell depletion, gadolinium chloride exerts on the liver other effects potentially relevant to the protection from aFas, such as a marked increase in TNF $\alpha$ mRNA levels, $\mathrm{NF}-\kappa \mathrm{B}$ activation or even stimulation of hepatocyte proliferation; of interest, all of these effects are suppressed by antiTNF $\alpha$ antibodies. ${ }^{21,46,47}$

Protection against aFas-mediated toxicity has also been observed in the regenerating liver. Indeed, mice at $24 \mathrm{~h}$ after two-thirds hepatectomy are resistant to aFas-induced toxicity, ${ }^{1,19}$ although the hepatocyte surface expression of Fas is unchanged. $^{19}$ On the other hand, sublethal doses of aFas afford protection against a subsequent lethal challenge with the same antibody, an effect that has been ascribed to the compensatory proliferation elicited by the first injection. ${ }^{1}$ In this context, the proliferation-promoting role of TNF $\alpha$ in the liver seems to be involved in the resistance to aFas-induced damage. Indeed, exogenous TNF $\alpha$ given $5 \mathrm{~h}$ before aFas in nonoperated animals and anti-TNF $\alpha$ antibodies given prior to hepatectomy, respectively, reduce and increase the susceptibility to aFas. ${ }^{19}$ Noteworthily, aFas itself accelerates the compensatory liver growth after partial hepatectomy. ${ }^{1}$ Altogether, the notion clearly emerges that, whatever their precise nature, mechanisms are activated in the regenerating liver to suppress not only TNFRs- but also Fas-mediated death signals, in contrast to their apparent cooperation in actuating aFas toxicity in the normal liver.

The present work does not discriminate whether TNFRs relay to hepatocytes stimuli from nonparenchymal cells, such as sinusoidal endothelial ${ }^{31}$ or Kupffer cells, ${ }^{45}$ or rather their signals integrate with those generated by Fas directly within the same cells targeted by aFas. Early studies already reported that surface TNFRs are internalized in Jurkat T cells undergoing apoptosis by aFas, ${ }^{48}$ while a recent report shows that TNFR2-null CD8 T cells are resistant to aFas treatment. ${ }^{49}$ Moreover, potential 'crosstalks' between the TNF $\alpha$-TNFRs and FasL-Fas signaling pathways have been hypothesized in view of the shared role of FADD ${ }^{50,51}$ and of other commonalities such as positive and negative regulators of the apoptotic cascades, JNK activation, and modulation of transcription factors such as $\mathrm{NF}-\kappa \mathrm{B}$ or $\mathrm{AP}-1$.

Finally, the $\mathrm{R}^{-}$phenotype might render liver cells inherently more resistant to aFas by modifying the expression profile or regulation of relevant gene products. The present work provides two relevant examples in this regard. Bcl-2 expression, comparable in untreated $\mathrm{R}^{+}$and $\mathrm{R}^{-}$animals, after aFas treatment was upregulated in $\mathrm{R}^{-}$mice only, suggesting the obvious speculation that in $\mathrm{R}^{+}$mice this upregulation might be prevented by the Fas-activated TNFRs signalling. TNF $\alpha$ has indeed been reported to suppress $\mathrm{Bcl}-2$ expression in hepatoma ${ }^{52}$ and microglial cells. ${ }^{40}$ Furthermore, the DNAbinding activity of $\mathrm{NF}-\kappa \mathrm{B}$, already slightly higher in $\mathrm{R}^{-}$than $\mathrm{R}^{+}$ controls, after aFas treatment was much more strongly activated in $\mathrm{R}^{-}$than in $\mathrm{R}^{+}$mice. Although the underlying mechanisms require further investigations, it seems concei- 
vable that these regulations may both concur to reduce the susceptibility of $R^{-}$mice to aFas.

\section{Materials and Methods}

\section{Animals and treatment}

The experiments have been performed using 8-week-old C57BL6 mice knocked out for both TNFRs ( $\mathrm{R}^{-}$mice), kindly provided by $\mathrm{Dr}$. $\mathrm{H}$ Bluethmann, Hoffmann-La Roche Ltd, Basel, Switzerland. Homozygous tnfr1/tnfr2 double knockout mice $\left(\mathrm{R}^{-}\right.$mice) were generated by crossbreeding tnfr $1^{-1-}$ and tnfr $2^{-1-}$ mice. ${ }^{53}$ C57BL6 mice (Charles River, Calco, Italy) have been used as controls ( $\mathrm{R}^{+}$mice). The animals have been housed and cared for in compliance with the Italian Ministry of Health Guidelines (n. 86/609/EEC) and with the Principles of Laboratory Animal Care (NIH n. 85-23, revised 1985).

Both $\mathrm{R}^{+}$and $\mathrm{R}^{-}$mice, weighing approximately $25-30 \mathrm{~g}$, received intravenously $10 \mu \mathrm{g}$ anti-Fas antibody (Jo2, Pharmingen, San Diego, CA, USA). $\mathrm{R}^{+}$mice became moribund within $5-8 \mathrm{~h}$ after treatment. Some of them were immediately killed under anesthesia with zoletil, while some others have been monitored to evaluate the exact time of death. A group of $\mathrm{R}^{-}$mice was killed $10 \mathrm{~h}$ after the injection of aFas, while some animals were monitored for the following $24 \mathrm{~h}$ to analyze survival. The liver was rapidly excised, partly frozen in liquid nitrogen and stored at $-80^{\circ} \mathrm{C}$, partly fixed in $4 \%(\mathrm{w} / \mathrm{v})$ paraformaldehyde or in $4 \%$ (v/v) Karnowski solution $(25 \%$ paraformaldehyde, $25 \%$ glutaraldehyde, $0.1 \mathrm{M}$ cacodylate buffer, $\mathrm{pH} 7.3$ ) and stored at $4^{\circ} \mathrm{C}$.

\section{Morphological analysis}

- Light microscopy

Different liver lobes previously fixed in paraformaldehyde were routinely embedded in paraffin. Slices $5 \boldsymbol{\mu}$ m thick were stained with hematoxylin and eosin. To better visualize chromatin, some slices were stained with DAPI (10 ng/ml in methanol), washed with PBS followed by absolute ethanol, mounted in Bacto-Fa (Difco, USA), and viewed in an epiilluminated fluorescence microscope (Dialux 20, Leitz, Germany).

- Electron microscopy

Tissues fixed in Karnowski solution were postfixed with 1\% (w/v) osmium tetroxide, dehydrated with sequencial passages in an acetone ascending series (50-70-90-100\%), and embedded in Epon. Graysilver ultrathin sections $(4 \mathrm{~nm})$, mounted on copper grids, were stained with uranyl acetate-lead nitrate, and examined with a Zeiss EM10 electron microscope.

- Immunohistochemistry

Tissues previously frozen in liquid nitrogen were embedded in O.C.T. compound (Miles, Elkhart, IN, USA). Slices $5 \mu \mathrm{m}$ thick (Leitz 1720 cryostat) were methanol-fixed, stained with anti-Fas primary antibody (1:50 overnight; Santa Cruz Biotechnology, Santa Cruz, CA, USA), and incubated with biotinylated goat anti-rabbit secondary antibody and streptavidin (LSAB2 kit, Dako, Milano, Italy). The reaction was developed with diaminobenzidine and $\mathrm{H}_{2} \mathrm{O}_{2}$ as chromogenic substrate.

\section{DNA fragmentation}

The occurrence of internucleosomal DNA fragmentation was evaluated by agarose gel electrophoresis as described by Kaufmann. ${ }^{54}$ The liver was homogenized with a Polytron apparatus in a lysis buffer (2 mM EDTA, $10 \mathrm{mM} \mathrm{NaCl}, 1 \%$ SDS, $500 \mathrm{mM}$ TRIS-HCl, pH 9.0), the homogenate incubated overnight at $48^{\circ} \mathrm{C}$ in the presence of proteinase $\mathrm{K}(20 \mathrm{mg} / \mathrm{ml})$ and DNA was extracted with the phenol-chloroform-isoamyl alcohol standard procedure. The resulting aqueous phase was incubated $60 \mathrm{~min}$ in the presence of $10 \mathrm{mg} / \mathrm{ml} \mathrm{RNAse}$ at $37^{\circ} \mathrm{C}$. Aliquots of $20 \mu \mathrm{g}$ DNA were electrophoresed on $1 \%$ agarose gel and viewed under UV illumination after staining with ethidium bromide.

\section{Western blotting}

The liver was homogenized in $80 \mathrm{mM}$ TRIS-HCl, pH 6.8, containing $0.1 \mathrm{M}$ DTT, $70 \mathrm{mM}$ SDS, and $1 \mathrm{mM}$ glycerol, kept in ice for $30 \mathrm{~min}$, centrifuged at $15000 \times g$ for $10 \mathrm{~min}$ at $4^{\circ} \mathrm{C}$, and the supernatants collected. Protein concentration was determined by the method of Lowry et al., ${ }^{55}$ using BSA as working standard. Equal amounts of proteins $(50 \mu \mathrm{g})$ were heatdenatured in sample-loading buffer $(50 \mathrm{mM}$ TRIS-HCl, pH 6.8, $100 \mathrm{mM}$ DTT, $2 \%$ SDS, $0.1 \%$ bromophenol blue, $10 \%$ glycerol), resolved by SDSpolyacrylamide gel electrophoresis ( $10 \%$ polyacrylamide, $0.1 \%$ SDS) and transferred to nitrocellulose membranes (Hybond C, Amersham Italia, Cologno Monzese, Milano, Italy). The filters were blocked with $5 \%$ PBS$\mathrm{BSA}$ at $4^{\circ} \mathrm{C}$ overnight, then incubated with polyclonal antibodies directed against Bcl-2, Fas, FasL, and $\mathrm{l}-\kappa \mathrm{B} \alpha$ (Santa Cruz Biotechnology, Santa Cruz, CA, USA). Horseradish peroxidase-conjugated goat anti-mouse IgG (Bio-Rad, Hercules, CA, USA) was used as secondary antibody. The membrane-bound immune complexes were detected by an enhanced chemiluminescence system (NEN, Boston, MA, USA).

\section{Enzymatic activities}

Liver samples were homogenized in $20 \mathrm{mM}$ HEPES-KOH, $\mathrm{pH} 7.5$, containing $10 \mathrm{mM} \mathrm{KCl}, 1.5 \mathrm{mM} \mathrm{MgCl} 2,1 \mathrm{mM}$ EDTA, $1 \mathrm{mM}$ EGTA, $1 \mathrm{mM}$ DTT, $1 \mathrm{mM}$ PMSF, frozen-thawed, sonicated and centrifuged (13000 r.p.m., $15 \mathrm{~min}, 4^{\circ} \mathrm{C}$ ). Aliquots of the supernatant corresponding to $10 \mu \mathrm{g}$ protein were diluted in $25 \mathrm{mM}$ HEPES pH 7.5, containing $0.1 \%$ CHAPS, $10 \%$ sucrose, $10 \mathrm{mM} \mathrm{DTT}$, and assayed for caspase 3-, 8-, and 9-like, calpain and cathepsin $B$ activities in the presence of the corresponding substrates (caspase 3: DEVD-AMC; caspase 8: IETD-AMC, caspase 9: LEHD-AMC; calpain: Suc-Leu-Tyr-AMC; cathepsin B: Z-Arg-Arg-AMC; Sigma). After $1 \mathrm{~h}$ incubation at $37^{\circ} \mathrm{C}$, the reaction was stopped with $0.1 \%$ TCA and fluorescence was read in a Perkin-Elmer fluorometer (excitation $380 \mathrm{~nm}$, emission $460 \mathrm{~nm}$ ). Free AMC was used as standard.

\section{Electrophoretic mobility shift assay}

Nuclear extracts from the liver have been obtained as described by $\mathrm{Xu}$ and et al. ${ }^{17}$ Briefly, the tissue has been homogenized in $20 \mathrm{mM}$ HEPES, pH 7.9, containing $350 \mathrm{mM} \mathrm{NaCl}, 1 \mathrm{mM} \mathrm{MgCl}, 0.5 \mathrm{mM}$ EDTA, $0.1 \mathrm{mM}$ EGTA, 20\% glycerol, 1\% Nonidet P-40, 0.1\% PMSF, $0.5 \mathrm{mM} \mathrm{DTT,} 10 \mu \mathrm{g} /$ $\mathrm{ml}$ leupeptin, and the nuclei isolated by centrifugation. Isolated nuclear fractions were lysed in a 1:1 mixture of the above buffer and another one containing $25 \mathrm{mM}$ HEPES, pH 7.6, $0.1 \mathrm{mM}$ EDTA, 20\% glycerol, $1 \mathrm{mM}$ PMSF, $1 \mathrm{mM} \mathrm{DTT}, 10 \mu \mathrm{g} / \mathrm{ml}$ leupeptin, and stored at $-80^{\circ} \mathrm{C}$ until used for assay.

Oligonucleotide labeling and binding reactions were performed by using the reagent supplied in the Gel Shift Assay System (Promega Italia, Milano, Italy). Nuclear proteins $(10 \mu \mathrm{g})$ were incubated at room temperature for $20 \mathrm{~min}$ in the presence of the ${ }^{32} \mathrm{P}$-ATP end-labeled, double-stranded NF- $\kappa$ B consensus oligonucleotide (Promega Italia, Milano, Italy), as directed by the manufacturer. At the end of the incubation, $0.1 \mathrm{vol}$ of $10 \times$ gel loading buffer $(250 \mathrm{mM}$ Tris- $\mathrm{HCl}, \mathrm{pH} 7.5$, $0.2 \%$ bromophenol blue, $40 \%$ glycerol) was added to the binding mixture 
and the samples electrophoresed in $0.5 \times$ TBE buffer at $350 \mathrm{~V}$ for $40 \mathrm{~min}$ on a $4 \%$ nondenaturing acrylamide gel. After electrophoresis, the gel was dried for $30 \mathrm{~min}$ in a BioRad Gel Dryer and exposed overnight or for longer times to an X-ray sensitive film (Hyperfilm-MP, Amersham Biosciences, Cologno Monzese, Milano, Italy) at $-80^{\circ} \mathrm{C}$ with intensifying screens. The specificity of the bands has been confirmed by adding an excess amount of cold oligonucleotide to the reaction mixture (not shown).

\section{Acknowledgements}

This work has been supported by the Ministero per l'Istruzione, l'Università e la Ricerca (MIUR, Roma; Italy-Spain Integrated Actions). P Aoki is recipient of a fellowship from the Fundacion Antorchas, Brazil.

\section{References}

1. Desbarats $J$ and Newell MK (2000) Fas engagement accelerates liver regeneration after partial hepatectomy. Nat. Med. 6: 920-923.

2. Tran SE, Holmstrom TH, Ahonen M, Kahari VM and Eriksson JE (2001) MAPK/ ERK overrides the apoptotic signaling from Fas, TNF, and TRAIL receptors. J. Biol. Chem. 276: 16484-16490.

3. Budd RC (2002) Death receptors couple to both cell proliferation and apoptosis. J. Clin. Invest. 109: 437-441.

4. Nagata S and Golstein P (1995) The Fas death factor. Science 267: 14491456

5. Scaffidi C, Fulda S, Srinivasan A, Friesen C, Li F, Tomaselli KJ, Debatin KM, Krammer PH and Peter ME (1998) Two CD95 (APO-1/Fas) signaling pathways. EMBO J. 17: 1675-1687.

6. Scaffidi C, Schmitz I, Zha J, Korsmeyer SJ, Krammer PH and Peter ME (1999) Differential modulation of apoptosis sensitivity in CD95 type I and type II cells. J. Biol. Chem. 274: 22532-22538.

7. Pinkoski MJ, Brunner T, Green DR and Lin T (2000) Fas and Fas ligand in gut and liver. Am. J. Physiol. Gastrointest. Liver Physiol. 278: G354-G366.

8. Galle PR, Hofmann WJ, Walczak H, Schaller H, Otto G, Stremmel W, Krammer PH and Runkel L (1995) Involvement of the CD95 (APO-1/Fas) receptor and ligand in liver damage. J. Exp. Med. 182: 1223-1230.

9. Hiramatsu N, Hayashi N, Katayama K, Mochizuki K, Kawanishi Y, Kasahara A Fusamoto $\mathrm{H}$ and Kamada T (1994) Immunohistochemical detection of Fas antigen in liver tissue of patients with chronic hepatitis C. Hepatology 19: 13541359.

10. Mochizuki K, Hayashi N, Hiramatsu N, Katayama K, Kawanishi Y, Kasahara A Fusamoto $\mathrm{H}$ and Kamada $\mathrm{T}$ (1996) Fas antigen expression in liver tissues of patients with chronic hepatitis B. J. Hepatol. 24: 1-7.

11. Kondo T, Suda T, Fukuyama H, Adachi M and Nagata S (1997) Essential roles of the Fas ligand in the development of hepatitis. Nat. Med. 3: 409-413.

12. Seishima M, Takemura M, Saito K, Ando K and Noma A (1997) Increased serum soluble Fas (sFas) concentrations in HCV-positive patients with liver cirrhosis. J. Hepatol. 27: 424-425.

13. Ni R, Tomita Y, Matsuda K, Ichihara A, Ishimura K, Ogasawara J and Nagata S (1994) Fas-mediated apoptosis in primary cultured mouse hepatocytes. Exp. Cell Res. 215: 332-337.

14. Ogasawara J, Watanabe-Fukunaga R, Adachi M, Matsuzawa A, Kasugai T, Kitamura Y, Itoh N, Suda T and Nagata S (1993) Lethal effect of the anti-Fas antibody in mice. Nature 364: 806-809.

15. Ledgerwood EC, Pober JS and Bradley JR (1999) Recent advances in the molecular basis of TNF signal transduction. Lab. Invest. 79: 1041-1050.

16. Rolfe M, James NH and Roberts RA (1997) Tumour necrosis factor alpha (TNF alpha) suppresses apoptosis and induces DNA synthesis in rodent hepatocytes: a mediator of the hepatocarcinogenicity of peroxisome proliferators? Carcinogenesis 18: 2277-2278

17. Xu Y, Jones BE, Neufeld DS and Czaja MJ (1998) Glutathione modulates rat and mouse hepatocyte sensitivity to tumor necrosis factor toxicity. Gastroenterology 115: 1229-1237.

18. Michalopoulos GK and DeFrances MC (1997) Liver regeneration. Science 276 60-66.
19. Takehara T, Hayashi N, Mita E, Kanto T, Tatsumi T, Sasaki Y, Kasahara A and Hori M (1998) Delayed Fas-mediated hepatocyte apoptosis during liver regeneration in mice: hepatoprotective role of TNF alpha. Hepatology 27: 1643-1651.

20. Yamada $Y$ and Fausto $N$ (1998) Deficient liver regeneration after carbon tetrachloride injury in mice lacking type 1 but not type 2 tumor necrosis factor receptor. Am. J. Pathol. 152: 1577-1589.

21. Rose ML, Bradford BU, Germolec DR, Lin M, Tsukamoto H and Thurman RG (2001) Gadolinium chloride-induced hepatocyte proliferation is prevented by antibodies to tumor necrosis factor alpha. Toxicol. Appl. Pharmacol. 170: 39-45.

22. Tiegs G, Wolter M and Wendel A (1989) Tumor necrosis factor is a terminal mediator in galactosamine/endotoxin-induced hepatitis in mice. Biochem. Pharmacol. 38: 627-631.

23. Mizuhara H, O'Neill E, Seki N, Ogawa T, Kusunoki C, Otsuka K, Satoh S, Niwa M, Senoh H and Fujiwara H (1994) T cell activation-associated hepatic injury: mediation by tumor necrosis factors and protection by interleukin 6 . J. Exp. Med. 179: 1529-1537.

24. Bradham CA, Plumpe J, Manns MP, Brenner DA and Trautwein C (1998) Mechanisms of hepatic toxicity. I. TNF-induced liver injury. Am. J. Physiol. 275: G387-G392.

25. Plumpe J, Malek NP, Bock CT, Rakemann T, Manns MP and Trautwein C (2000) NF-kappaB determines between apoptosis and proliferation in hepatocytes during liver regeneration. Am. J. Physiol. Gastrointest. Liver Physiol. 278: G173-G183.

26. Jones BE, Lo CR, Liu H, Pradhan Z, Garcia L, Srinivasan A, Valentino KL and Czaja MJ (2000) Role of caspases and NF-kappaB signaling in hydrogen peroxide- and superoxide-induced hepatocyte apoptosis. Am. J. Physiol. Gastrointest. Liver Physiol. 278: G693-G699.

27. Czaja MJ (2001) TNF toxicity - death from caspase or cathepsin, that is the question. Hepatology 34: 844-846.

28. Leist M, Gantner F, Bohlinger I, Tiegs G, Germann PG and Wendel A (1995) Tumor necrosis factor-induced hepatocyte apoptosis precedes liver failure in experimental murine shock models. Am. J. Pathol. 146: 1220-1234.

29. Bulfone-Paus S, Ungureanu D, Pohl T, Lindner G, Paus R, Ruckert R, Krause $\mathrm{H}$ and Kunzendorf $U$ (1997) Interleukin-15 protects from lethal apoptosis in vivo. Nat. Med. 3: 1124-1128.

30. Bulfone-Paus S, Bulanova E, Pohl T, Budagian V, Durkop H, Ruckert R, Kunzendorf U, Paus R and Krause H (1999) Death deflected: IL-15 inhibits TNF-alpha-mediated apoptosis in fibroblasts by TRAF2 recruitment to the IL15Ralpha chain. FASEB J. 13: 1575-1585.

31. Wanner GA, Mica L, Wanner-Schmid E, Kolb SA, Hentze H, Trentz $\mathrm{O}$ and Ertel W (1999) Inhibition of caspase activity prevents CD95-mediated hepatic microvascular perfusion failure and restores Kupffer cell clearance capacity. FASEB J. 13: 1239-1248.

32. Hoglen NC, Hirakawa BP, Fisher CD, Weeks S, Srinivasan A, Wong AM, Valentino KL, Tomaselli KJ, Bai X, Karanewsky DS and Contreras PC (2001) Characterization of the caspase inhibitor IDN-1965 in a model of apoptosis-associated liver injury. J. Pharmacol. Exp. Ther. 297: 811-818.

33. Ruiz-Vela A, Gonzalez de Buitrago G and Martinez-A C (1999) Implication of calpain in caspase activation during $B$ cell clonal deletion. EMBO J. 18: 49884998.

34. Chen M, He H, Zhan S, Krajewski S, Reed JC and Gottlieb RA (2001) Bid is cleaved by calpain to an active fragment in vitro and during myocardial ischemia/reperfusion. J. Biol. Chem. 276: 30724-30728.

35. Varghese J, Radhika G and Sarin A (2001) The role of calpain in caspase activation during etoposide induced apoptosis in T cells. Eur. J. Immunol. 31: 2035-2041.

36. Ding WX, Shen HM and Ong CN (2002) Calpain activation after mitochondrial permeability transition in microcystin-induced cell death in rat hepatocytes. Biochem. Biophys. Res. Commun. 291: 321-331.

37. Deiss LP, Galinka H, Berissi H, Cohen O and Kimchi A (1996) Cathepsin D protease mediates programmed cell death induced by interferon-gamma, Fas/ APO-1 and TNF-alpha. EMBO J. 15: 3861-3870.

38. Foghsgaard L, Wissing D, Mauch D, Lademann U, Bastholm L, Boes M, Elling $F$, Leist M and Jaattela M (2001) Cathepsin B acts as a dominant execution protease in tumor cell apoptosis induced by tumor necrosis factor. J. Cell Biol. 153: $999-1010$. 
39. Guicciardi ME, Deussing J, Miyoshi H, Bronk SF, Svingen PA, Peters C, Kaufmann SH and Gores GJ (2000) Cathepsin B contributes to TNF-alphamediated hepatocyte apoptosis by promoting mitochondrial release of cytochrome c. J. Clin. Invest. 106: 1127-1137.

40. Spanaus KS, Schlapbach R and Fontana A (1998) TNF-alpha and IFN-gamma render microglia sensitive to Fas ligand-induced apoptosis by induction of Fas expression and down-regulation of Bcl-2 and Bcl-xL. Eur. J. Immunol. 28: 4398-4408

41. Lacronique V, Mignon A, Fabre M, Viollet B, Rouquet N, Molina T, Porteu A, Henrion A, Bouscary D, Varlet $P$, Joulin V and Kahn A (1996) Bcl-2 protects from lethal hepatic apoptosis induced by an anti-Fas antibody in mice. Nat. Med. 2: 80-86.

42. Rodriguez I, Matsuura K, Khatib K, Reed JC, Nagata S and Vassalli P (1996) A bcl-2 transgene expressed in hepatocytes protects mice from fulminant liver destruction but not from rapid death induced by anti-Fas antibody injection. J. Exp. Med. 183: 1031-1036.

43. Mukherjee D, Kaestner KH, Kovalovich KK and Greenbaum LE (2001) Fasinduced apoptosis in mouse hepatocytes is dependent on C/EBPbeta. Hepatology 33: 1166-1172.

44. Chung JY, Park YC, Ye H and Wu H (2002) All TRAFs are not created equal: common and distinct molecular mechanisms of TRAF-mediated signal transduction. J. Cell Sci. 115: 679-688.

45. Matsuki Y, Li L, Hsu HC, Yang PA, Zheng R, Edwards III CK, Chaudry IH, Zhang HG and Mountz JD (2002) Soluble Fas gene therapy protects against Fas-mediated apoptosis of hepatocytes but not the lethal effects of Fasinduced TNF-alpha production by Kupffer cells. Cell Death Differ. 9: 626-635.

46. Rai RM, Zhang JX, Clemens MG and Diehl AM (1996) Gadolinium chloride alters the acinar distribution of phagocytosis and balance between pro- and anti-inflammatory cytokines. Shock 6: 243-247.

47. Rai RM, Loffreda S, Karp CL, Yang SQ, Lin HZ and Diehl AM (1997) Kupffer cell depletion abolishes induction of interleukin-10 and permits sustained overexpression of tumor necrosis factor alpha messenger RNA in the regenerating rat liver. Hepatology 25: 889-895.

48. Yonehara S, Ishii A and Yonehara M (1989) A cell-killing monoclonal antibody (anti-Fas) to a cell surface antigen co-downregulated with the receptor of tumor necrosis factor. J. Exp. Med. 169: 1747-1756.

49. Teh HS, Seebaran A and Teh SJ (2000) TNF receptor 2-deficient CD8 T cells are resistant to Fas/Fas ligand-induced cell death. J. Immunol. 165: 4814-4821.

50. Varfolomeev EE, Boldin MP, Goncharov TM and Wallach D (1996) A potential mechanism of 'cross-talk' between the p55 tumor necrosis factor receptor and Fas/AP01: proteins binding to the death domains of the two receptors also bind to each other. J. Exp. Med. 183: 1271-1275.

51. Bang S, Jeong EJ, Kim IK, Jung YK and Kim KS (2000) Fas- and tumor necrosis factor-mediated apoptosis uses the same binding surface of FADD to trigger signal transduction. A typical model for convergent signal transduction. J. Biol. Chem. 275: 36217-36222.

52. Kim BC, Kim HT, Mamura M, Ambudkar IS, Choi KS and Kim SJ (2002) Tumor necrosis factor induces apoptosis in hepatoma cells by increasing $\mathrm{Ca}(2+)$ release from the endoplasmic reticulum and suppressing $\mathrm{Bcl}-2$ expression. J. Biol. Chem. 277: 31381-31389.

53. Kalb A, Bluethmann H, Moore MW and Lesslauer W (1996) Tumor necrosis factor receptors (Tnfr) in mouse fibroblasts deficient in Tnfr1 or Tnfr2 are signaling competent and activate the mitogen-activated protein kinase pathway with differential kinetics. J. Biol. Chem. 271: 28097-28104.

54. Kaufmann SH (1989) Induction of endonucleolytic DNA cleavage in human acute myelogenous leukemia cells by etoposide, camptothecin, and other cytotoxic anticancer drugs: a cautionary note. Cancer Res. 49: 5870-5878.

55. Lowry OH, Rosebrough NJ, Farr AL and Randall (1951) Protein measurement with the Folin phenol reagent. J. Biol. Chem. 193: 265-275. 